\title{
A Review on the Effects of Cadmium Stress on Growth and Development of Plants
}

\author{
Muhammad $\mathrm{Ali}^{1 *}$, Lurwan Mu'azu ${ }^{2}$ \\ ${ }^{\mathrm{T}}$ Department of Microbiology, Federal University Gusau Nigeria \\ ${ }^{2}$ Department of Biological Sciences, Federal University Gusau Nigeria
}

\section{*Corresponding Author}

Muhammad Ali

\section{Article History}

Received: 07.06.2020

Accepted: 16.06.2020

Published: 17.06.2020

\begin{abstract}
Cadmium (Cd) is a non-essential element readily taken up by the plants. Cadmium negatively affects plant metabolism affecting growth and development. It is released into the environment by a number of sources including power stations, metal working industries, heating systems, batteries and urban traffic. Cadmium is recognized as an extremely deleterious pollutant due to its high toxicity and large solubility in water, and has been ranked among the top toxins. Having significant concern with plant and human health, Cadmium has been widely studied for its impacts on plant at various levels including metabolism. The objective of this paper is to review the effect of cadmium stress on growth and development in plants.
\end{abstract}

Keywords: Cadmium, Growth and development, Heavy metals, Plants.

\section{INTRODUCTION}

Heavy metals are significant environmental pollutants [1] and their availability in soils depends on natural process, especially lithogenic and pedogenic, but also on anthropogenic factors such as mining, combustion of fossil fuels, urban waste disposal, soil runoff, metal working industries, boating activities, phosphate fertilizer application, sewage treatment plant effluents, and municipal solid waste disposal sites. Increase in levels of heavy metals in soils could also be attributed to factors such as soil properties or different agricultural practices, for example application of sludge to agricultural land [2]. Household waste, municipal and industrial waste are also sources of heavy metals to soil [3]. Soil contaminated with the heavy metals above the permissible limit lead to declines in agricultural yields [4,5]. The accumulation of heavy metals in the environment is now becoming a major cause of environmental pollution.

Cadmium $(\mathrm{Cd})$ is a naturally occurring metal situated in the Periodic Table of the Elements between zinc ( $\mathrm{Zn}$ ) and mercury $(\mathrm{Hg})$, with chemical behavior similar to $\mathrm{Zn}$. It generally exists as a divalent cation, complexed with other elements (e.g., $\mathrm{CdCl}_{2}$ ). Cadmium exists in the earth's crust at about 0.1 part per million, usually being found as an impurity in $\mathrm{Zn}$ or lead $(\mathrm{Pb})$ deposits, and therefore being produced primarily as a byproduct of $\mathrm{Zn}$ or $\mathrm{Pb}$ smelting [6]. The concentration of $\mathrm{Cd}$ in non-polluted soil solution ranges from $0.04 \mathrm{mM}$ to $0.32 \mathrm{mM}$, and its concentration in the range of 0.32 to about $1 \mathrm{mM}$ may be categorized as polluted [7].

Cadmium accumulation in plants has multiple direct and indirect effects on plant growth and alters many physiological functions [8] by forming complexes with $\mathrm{O}, \mathrm{N}$ and $\mathrm{S}$ ligands [9]. They interfere with mineral uptake [10] protein metabolism [11] membrane functioning [12] water relations and seed germination [13]. Cadmium inhibited net photosynthesis in green algae, corn, soybean, and pigeon pea [14-16], $\mathrm{O}_{2}$ evolution in Anacystis nedulens and photosystem II (PS II) in isolated chloroplasts of maize and spinach [14]. Moreover, they cause metabolic disturbance by altering essential biochemical reactions [17].

Copyright @ 2020: This is an open-access article distributed under the terms of the Creative Commons Attribution license which permits unrestricted use, distribution, and reproduction in any medium for non commercial use (NonCommercial, or CC-BY-NC) provided the original author and source are credited. 


\section{Cadmium}

Cadmium is non-essential element that negatively affects plant growth and development. It is released into the environment by power stations, heating systems, metal working industries or urban traffic. Cadmium is recognized as an extremely significant pollutant due to its high toxicity and large solubility in water [18]. Important sources of cadmium input to the marine environment include atmospheric deposition, domestic waste water and industrial discharges [19]. Wagner [20] estimated that non-polluted soil solutions contain cadmium concentrations range from 0.04 to $0.32 \mathrm{mM}$. Soil solutions which have a cadmium concentration varying from 0.32 to about $1 \mathrm{mM}$ can be regarded as polluted to a moderate level [21]. Hence, cadmium classified as an element of intermediate toxicity, but the mechanisms of cadmium toxicity are not completely understood yet. Stomatal Opening, Transpiration and Photosynthesis affected by cadmium, and Chlorosis, Leaf Rolls and Stunting are the main symptoms of cadmium toxicity in plants [22]. Cadmium also reduced the absorption of nitrate and its transport from root to shoot by inhibiting the Nitrate Reductase activity in shoots [23]. Several researches have suggested that an oxidative stress could be involved in cadmium toxicity, by either inducing oxygen free radical production, or by decreasing enzymatic and non-enzymatic antioxidants [22].

\section{Cadmium Stress in Plants}

\section{Effect of on fresh and dry mass}

The inhibiting effect of Cadmium on fresh and dry mass accumulation, height, root length, leaf area, and other biometric parameters of plants are reported in almost all investigations. The interaction of Rhizobium in the nodules of chickpea was found to be very sensitive to heavy metals resulting in a decrease in dry mass of chickpea and green gram [24]. An increase in Cadmium concentration decreased the fresh mass in mung bean [25]. Moreover, a marked decrease in root and shoot mass of Vigna ambacensis was observed when treated with low concentration of Cadmium [26].

\section{Effect on the plant growth}

Cadmium is not an essential nutrient and at high concentration inhibits plant growth [27]. It has also been reported that even at relatively low concentrations it alters plant metabolism [9]. The presence of cadmium in the soil decreases the growth of soybean [28] and chickpea plants [29]. High concentrations of Cadmium decreased cell growth as well as whole plant growth [30].

\section{Effect on photosynthesis}

Cadmium is an effective inhibitor of photosynthesis [31]. A linear relationship between photosynthesis and inhibition of transpiration was observed in soybean that suggests Cadmium inhibited stomatal opening [32]. Cadmium damages the photosynthetic apparatus, in particular the light harvesting complex II [33] and photosystems I and II [34]. The inhibition of root $\mathrm{Fe}^{3+}$ reductase induced by Cadmium leads to $\mathrm{Fe}^{2+}$ deficiency which seriously affects photosynthesis [35]. Cadmium also causes stomatal closure in higher plants [36] and an overall inhibition of photosynthesis [37].

\section{Effect on chlorophyll and protein content}

The presence of Cadmium decreased the content of chlorophyll and carotenoids, and increased nonphotochemical quenching in Brassica napus [38]. Similarly, the synthesis and level of chlorophyll decreased in other plant species under the influence of the cadmium $[39,40]$. Growth reduction associated with cadmium treatment was probably caused by inhibition of protein synthesis [2]. Phytotoxicity of the metal in other crop plants has been observed in the form of a loss in protein levels [11]. Moreover, the grains developed on the plants grown under Cadmium stress had lower protein content [41].

\section{Effect on nodulation}

The presence of heavy metals such as cadmium in the soil decreased the yield of symbiotic nitrogen- fixing organisms and the number of nodules per plant [42]. The presence of Cadmium decreased nodulation and nitrogenase activity in Phaseolus vulgaris [28,42], Trifolium repens [43], soybean [44], Alnus rubra [45] and in Pisum sativum [46]. Nitrogen assimilation in pea plants was severely affected on exposure to Cadmium [23, 46]. A positive correlation was observed between leghemoglobin content and nitrogenase activity [47] and both these parameters exhibited a parallel decrease in the presence of Cadmium [48]. The oxidation stress generated by $\mathrm{Cd}^{2+}$ accelerated senescence of nodules in soybean plants [49].

\section{Effect on nitrate reductase activity}

Nitrate reductase (NR), the primary enzyme in the nitrate assimilation pathway, is the limiting factor in plant growth and development [51] and its level is influenced by a variety of environmental factors [51]. The presence of Cadmium in the soil affected the assimilation of $\mathrm{NO}_{3}$ in maize [23,52], pea [53], Silene vulgaris [54], bean and tomato [55] and in Cicer arietinum [56]. 


\section{Effect on antioxidant systems}

Plants possess a number of antioxidant systems that protect them from oxidative damage [57]. Superoxidase (SOD) is the first enzyme in the detoxifying process that converts $\mathrm{O}_{2}$ - radicals to $\mathrm{H}_{2} \mathrm{O}_{2}$ at a very rapid rate [58]. Cadmium was found to result in oxidative stress [59] by either inducing oxygen free radical production [60] or by decreasing concentrations of enzymatic and non-enzymatic antioxidants [61]. These defense systems are composed of metabolites such as ascorbate, glutathione, tocopherol, etc., and enzymatic scavengers of activated oxygen such as peroxidases, catalases and superoxide dismutases [62]. Peroxidase induction is a general response of higher plants after uptake of toxic quantities of metals [9]. Cadmium ions can inhibit or sometimes stimulate the activity of several antioxidative enzymes. In Halianthus annuиs leaves, Cadmium enhanced lipid peroxidation, increased lipoxygenase activity and decreased the activity of superoxidase [63], glutathione reductase, catalase, ascorbate peroxidase, glutathione reductase and dehydroascorbate reductase [64]. Cadmium induced the activity of peroxidase (POX) in soybean [65], bean leaves [66] and in roots and leaves of Oryza sativa [67].

\section{CONCLUSION}

Cadmium is a non-essential element readily taken up by the plants. Cadmium negatively affects plant metabolism affecting growth and development, nodulation, chlorophyll and protein content, as well as photosynthesis rate. Cadmium also reduced the absorption of nitrate and its transport from root to shoot by inhibiting the Nitrate Reductase activity.

\section{REFERENCES}

1. Kevrešan, S., Krstić, B., Popović, M., Kovačev, L., Pajević, S., \& Kandrač, J. (1997). Biochemical changes in sugar beet lines in dependence on soil moisture. Biologia plantarum, 40(2), 245-250.

2. Foy, C. D., Chaney, R. T., \& White, M. C. (1978). The physiology of metal toxicity in plants. Annual review of plant physiology, 29(1), 511-566.

3. Alloway, B.J.(1995). Heavy metal in soils. Blackie Academic and Professional, New York, 368.

4. Salt, D. E., \& Rauser, W. E. (1995). MgATP-dependent transport of phytochelatins across the tonoplast of oat roots. Plant Physiology, 107(4), 1293-1301.

5. Akinola, M. O., \& Ekiyoyo, T. A. (2006). Accumulation of lead, cadmium and chromium in some plants cultivated along the bank of river Ribila at Odo-nla area of Ikorodu, Lagos state, Nigeria. Journal of Environmental Biology, 27(3), 597-599.

6. Wedepohl, K. H. (1995). The composition of the continental crust. Geochimica et cosmochimica Acta, 59(7), $1217-$ 1232.

7. Di Toppi, L. S., \& Gabbrielli, R. (1999). Response to cadmium in higher plants. Environmental and experimental botany, 4l(2), 105-130.

8. Lange, O. L., Nobel, P. S., Osmond, C. B., \& Ziegler, H. (2013). Physiological plant ecology III: Responses to the chemical and biological environment (Vol. 12). Springer Science \& Business Media.

9. Van Assche, F., \& Clijsters, H. (1990). Effects of metals on enzyme activity in plants. Plant, Cell \& Environment, 13(3), 195-206.

10. Adhikari, T., Tel-Or, E., Libal, Y., \& Shenker, M. (2006). Effect of cadmium and iron on rice (Oryza sativa L.) plant in chelator-buffered nutrient solution. Journal of plant nutrition, 29(11), 1919-1940.

11. Tamás, L., Huttová, J., \& Žigová, Z. (1997). Accumulation of stress-proteins in intercellular spaces of barley leaves induced by biotic and abiotic factors. Biologia plantarum, 39(3), 387-394.

12. Azevedo, H., Glória Pinto, C. G., \& Santos, C. (2005). Cadmium effects in sunflower: membrane permeability and changes in catalase and peroxidase activity in leaves and calluses. Journal of plant nutrition, 28(12), 2233-2241.

13. Al-Helal, A. A. (1995). Effect of cadmium and mercury on seed germination and early seedling growth of rice and alfalfa. Journal-univeRsity of Kuwait science, 22, 76-76.

14. Bazzaz, F. A., Carlson, R. W., \& Rolfe, G. L. (1974). The effect of heavy metals on plants: Part I. Inhibition of gas exchange in sunflower by $\mathrm{Pb}, \mathrm{Cd}, \mathrm{Ni}$ and Tl. Environmental Pollution (1970), 7(4), 241-246.

15. Sheoran, I. S., Singal, H. R., \& Singh, R. (1990). Effect of cadmium and nickel on photosynthesis and the enzymes of the photosynthetic carbon reduction cycle in pigeonpea (Cajanus cajan L.). Photosynthesis Research, 23(3), 345351.

16. Krupa, Z., Öquist, G., \& Huner, N. P. (1993). The effects of cadmium on photosynthesis of Phaseolus vulgaris-a fluorescence analysis. Physiologia Plantarum, 88(4), 626-630.

17. Kaiser, W. M. (2005). Mineral Nutrition of Plants: Principles and Perspectives, E. Epstein, A. Bloom, Sinauer Associates, Inc. Publishers, Sunderland, MA (2004),(400pp., US \$79.95), ISBN: 0-87893-172-4.

18. Pinto, A. P., Mota, A. D., De Varennes, A., \& Pinto, F. C. (2004). Influence of organic matter on the uptake of cadmium, zinc, copper and iron by sorghum plants. Science of the total environment, 326(1-3), 239-247.

19. Baek, K. H., Chang, J. Y., Chang, Y. Y., Bae, B. H., Kim, J., \& Lee, I. (2006). Phytoremediation of soil contaminated with cadmium and/or 2, 4, 6-Trinitrotoluene. Journal of environmental biology, 37(2), 311-316. 
20. Wagner, G. J. (1993). Accumulation of cadmium in crop plants and its consequences to human health. Advances in agronomy, 51, 173-212.

21. Benavides, M. P., Gallego, S. M., \& Tomaro, M. L. (2005). Cadmium toxicity in plants. Brazilian journal of plant physiology, 17(1), 21-34.

22. Sandalio, L. M., Dalurzo, H. C., Gomez, M., Romero-Puertas, M. C., \& Del Rio, L. A. (2001). Cadmium-induced changes in the growth and oxidative metabolism of pea plants. Journal of experimental botany, 52(364), 2115-2126.

23. Hasan, S. A., Fariduddin, Q., Ali, B., Hayat, S., \& Ahmad, A. (2009). Cadmium: toxicity and tolerance in plants. $J$ Environ Biol, 30(2), 165-174.

24. Athar, R., \& Ahmad, M. (2002). Heavy metal toxicity in legume-microsymbiont system. Journal of plant nutrition, 25(2), 369-38

25. Shen, X. Y., Dai, J. Y., Hu, A. C., Gu, W. L., He, R. Y., \& Zheng, B. (1990). Studies on physiological effects of brassinolide on drought resistance in maize. Journal of Shenyang Agricultural University, 21(3), 191-195.

26. Al-Yemeni, M. N. (2001). Effect of cadmium, mercury and lead on seed germination and early seedling growth of Vigna ambacensis L. Indian Journal of Plant Physiology, 6(2), 147-151.

27. Aery, N. C., \& Rana, D. K. (2003). Growth and cadmium uptake in barley under cadmium stress. Journal of environmental biology, 24(2), 117-123.

28. Dowdy, R. H., \& Ham, G. E. (1977). Soybean Growth and Elemental Content as Influenced by Soil Amendments of Sewage Sludge and Heavy Metals: Seedling Studies 1. Agronomy Journal, 69(2), 300-303.

29. Hasan, S. A., Hayat, S., Ali, B., \& Ahmad, A. (2008). 28-Homobrassinolide protects chickpea (Cicer arietinum) from cadmium toxicity by stimulating antioxidants. Environmental pollution, 151(1), 60-66.

30. Prasad, M. N. V. (1995). Cadmium toxicity and tolerance in vascular plants. Environmental and Experimental Botany, 35(4), 525-545.

31. Vassilev, A., Perez-Sanz, A., Semane, B., Carleer, R., \& Vangronsveld, J. (2005). Cadmium accumulation and tolerance of two Salix genotypes hydroponically grown in presence of cadmium. Journal of plant nutrition, 28(12), 2159-2177.

32. Barcelo, J., Poschenrieder, C., Andreu, I., \& Gunse, B.(1986). Cadmium induced decrease of water stress resistance in bush bean plants (Phaseolus vulgaris L. cv. Vontendev). I. Effect of Cd on water potential, relations water content and cell wall elasticity. J. Plant Physiol, 125, 17-25

33. Krupa, Z. (1988). Cadmium-induced changes in the composition and structure of the light-harvesting chlorophyll a/b protein complex II in radish cotyledons. Physiologia Plantarum, 73(4), 518-524.

34. Siedlecka, A., \& Krupa, Z. (1996). Interaction between cadmium and iron and its effects on photosynthetic capacity of primary leaves of Phaseolus vulgaris. Plant physiology and biochemistry (Paris), 34(6), 833-841.

35. Alkantara, E., Romerza, F.J., Canett, M., \& De LaGuardia, M.D.(1994). Effect of heavy metals on both induction and function of root Fe (III) reductase in Fe-deficient cucumber (Cucumis sativus L.) plants. J. Exp. Botany, 45, 1893-1898

36. Poschenrieder, C., Gunse, B., \& Barcelo, J. (1989). Influence of cadmium on water relations, stomatal resistance, and abscisic acid content in expanding bean leaves. Plant Physiology, 90(4), 1365-1371.

37. Chugh, L. K., \& Sawhney, S. K. (1999). Photosynthetic activities of Pisum sativum seedlings grown in presence of cadmium. Plant physiology and biochemistry, 37(4), 297-303.

38. Larsen, P. B., Degenhart, L. M., \& Stenzler, S. H. Howell and Kochian, LV (1998). Aluminium-resistant Arabidopsis mutant that exhibit altered pattern of aluminium accumulation and organic acid release from roots. Plant Physiology, 117, 9-18.

39. Phetsombat, S., Kruatrachue, M., Pokethitiyook, P., \& Upatham, S. (2006). Toxicity and bioaccumulation of cadmium and lead in Salvinia cucullata. Journal of Environmental Biology, 27(4), 645-652.

40. Pandey, S., Gupta, K., \& Mukherjee, A. K. (2007). Impact of cadmium and lead on Catharanthus roseus-A phytoremediation study. Journal of Environmental Biology, 28(3), 655.

41. Salgare, S. A., \& Acharekar, C. (1992). Effect of industrial pollution on growth and content of certain weeds. J. Nature Conserve, 4, 1-6.

42. Vigue, G. T., Pepper, I. L., \& Bezdicek, D. F. (1981). The Effect of Cadmium on Nodulation and N2 (C2H2)Fixation by Dry Beans (Phaseolus vulgaris L.). Journal of Environmental Quality, 10(1), 87-90.

43. McGrath, S. P., Brookes, P. C., \& Giller, K. E. (1988). Effects of potentially toxic metals in soil derived from past applications of sewage sludge on nitrogen fixation by Trifolium repens L. Soil Biology and Biochemistry, 20(4), 415-424.

44. Vesper, S. J., \& Weidensaul, T. C. (1978). Effects of cadmium, nickel, copper, and zinc on nitrogen fixation by soybeans. Water, Air, and Soil Pollution, 9(4), 413-422.

45. Wickliff, C., Evans, H. J., Carter, K. R., \& Russell, S. A. (1980). Cadmium effects on the nitrogen fixation system of red alder. Journal of Environmental Quality, 9(2), 180-184.

46. Dhingra, H. R., \& Priefer, U. B. (2006). Impact of Cadmium on Structural and Functional Aspects of Pea (Pisum sativum L.) Root Nodules. JOURNAL OF PLANT BIOLOGY-NEW DELHI, 33(3), 201. 
47. Comba, M. E., Benavides, M. P., Gallego, S. M., \& Tomaro, M. L. (1997). Relationship between nitrogen fixation and oxidative stress induction in nodules of salt-treated soybean plants. Phyton.

48. Fernández-Pascual, M., De Lorenzo, C., De Felipe, M. R., Rajalakshmi, S., Gordon, A. J., Thomas, B. J., \& Minchin, F. R. (1996). Possible reasons for relative salt stress tolerance in nodules of white lupin cv. Multolupa. Journal of Experimental Botany, 47(11), 1709-1716.

49. Balestrasse, K. B., Gardey, L., Gallego, S. M., \& Tomaro, M. L. (2001). Response of antioxidant defence system in soybean nodules and roots subjected to cadmium stress. Functional Plant Biology, 28(6), 497-504.

50. Solomonson, L. P., \& Barber, M. J. (1990). Assimilatory nitrate reductase: functional properties and regulation. Annual review of plant biology, 41(1), 225-253.

51. ANDREWS, M. (1986). The partitioning of nitrate assimilation between root and shoot of higher plants. Plant, Cell \& Environment, 9(7), 511-519.

52. Nussbaum, S., Schmutz, D., \& Brunold, C. (1988). Regulation of assimilatory sulfate reduction by cadmium in Zea mays L. Plant Physiology, 88(4), 1407-1410.

53. Burzyński, M. (1988). The uptake and accumulation of phosphorous and nitrates and the activity of nitrate reductase in cucumber seedlings treated with $\mathrm{PbCl} 2$ or CdCl2. Acta Societatis Botanicorum Poloniae, 57(3), 349-359.

54. MATHYS, W. (1975). Enzymes of heavy-metal-resistant and non-resistant populations of Silene cucubalus and their interaction with some heavy metals in vitro and in vivo. Physiologia Plantarum, 33(2), 161-165.

55. Ouariti, O., Gouia, H., \& GHORBAL, M. H. (1997). Responses of bean and tomato plants to cadmium: growth, mineral nutrition, and nitrate reduction. Plant physiology and biochemistry (Paris), 35(5), 347-354.

56. Ali, B., Rani, I., Hayat, S., \& Ahmad, A. (2007). Effect of 4-Cl-indole-3-acetic acid on the seed germination of Cicer arietinum exposed to cadmium. Acta Botanica Croatica, 66(1), 57-65.

57. Pál, M., Horváth, E., Janda, T., Páldi, E., \& Szalai, G. (2006). Physiological changes and defense mechanisms induced by cadmium stress in maize. Journal of Plant Nutrition and Soil Science, 169(2), 239-246.

58. Polle, A., \& Rennenberg, H. (1994). Photooxidative stress in trees. In 'Causes of photooxidative stress and amelioration of defense systems in plants'.(Eds CH Foyer, PM Mullineaux) pp. 199-218.

59. Hendry, G. A. F., Baker, A. J. M., \& Ewart, C. F. (1992). Cadmium tolerance and toxicity, oxygen radical processes and molecular damage in cadmium-tolerant and cadmium-sensitive clones of Holcus lanatus L. Acta Botanica Neerlandica, 41(3), 271-281.

60. Demirevska-Kepova, K., Simova-Stoilova, L., Stoyanova, Z. P., \& Feller, U. (2006). Cadmium stress in barley: growth, leaf pigment, and protein composition and detoxification of reactive oxygen species. Journal of plant nutrition, 29(3), 451-468.

61. Mohan, B. S., \& Hosetti, B. B. (2006). Phytotoxicity of cadmium on the physiological dynamics of Salvinia natans L. grown in macrophyte ponds. Journal of Environmental Biology, 27(4), 701-704.

62. Mandhania, S., Madan, S., \& Sawhney, V. (2006). Antioxidant defense mechanism under salt stress in wheat seedlings. Biologia Plantarum, 50(2), 227-231.

63. Panda, S. K. (2003). Salt stress influences lipid peroxidation and antioxidants in the leaf of an indica rice (Oryza sativa L). Physiol. Mol. Biol. Plants, 9, 273-278.

64. Gallego, S. M., Benavides, M. P., \& Tomaro, M. L. (1996). Effect of heavy metal ion excess on sunflower leaves: evidence for involvement of oxidative stress. Plant Science, 121(2), 151-159.

65. Fuhrer, J. (1982). Ethylene biosynthesis and cadmium toxicity in leaf tissue of beans (Phaseolus vulgaris L.). Plant Physiology, 70(1), 162-167.

66. Lee, J. G., Ahner, B. A., \& Morel, F. M. (1996). Export of cadmium and phytochelatin by the marine diatom Thalassiosira weissflogii. Environmental science \& technology, 30(6), 1814-1821.

67. REDDY, G. N., \& PRASAD, M. V. (1993). Tyrosine is not phosphorylated in cadmium induced hsp70 cognate in maize (Zea mays L.) seedlings: Role in chaperone function?. Biochemical archives, 9(1), 27-32. 